\title{
STRATEGI PENGUATAN MODAL SOSIAL DALAM PELAKSANAAN PROGRAM KAMPUNG KB DI KABUPATEN PELALAWAN DAN KOTA PEKANBARU PROVINSI RIAU
}

\author{
Nur laila Meilani ${ }^{1}$, Bascoro Wicaksono, Sri Lilestina ${ }^{2}$, Aning Tri Subeqi \\ Universitas Riau ${ }^{1}$, Puslitbang KB \& KS BKKBN Pusat ${ }^{2}$ \\ e-mail: meilanimeilani09@gmail.com ${ }^{1}$ \\ e-mail : srililestinabkkbn@gmail.com²
}

\begin{abstract}
The fact that the KB Village experienced "torpor" after the declaration became an indisputable thing. On the other hand, the results of the study by Meilani et al (2017) found that in fact the community was very much waiting for a more real and periodic follow-up in the context of implementing the KB Village. This study aims to identify and analyze existing conditions of social capital in the implementation of the KB Village Program in Riau Province. Conceptually, social capital is derived into 4 (four) aspects, namely values and norms / NN, trust and reciprocity / TRC, information / INF, and networking / NW. Data is collected through observation and in-depth interviews. Informants consist of: (a) KB Village Management, (b) Religious leaders and community leaders in KB Village, and (c) Village Head / Village Head. Qualitative data analysis is done by interactive models. The results of the study showed that the presence of individuals who brought the spirit of altruism and sincerity to continue to live the $K B$ Village in fact greatly determined the activeness of the KB Village. In addition, qualitatively it was also identified that it was not about kinship or existing or not budgetary relationships that determined the activeness of the KB Village, but the actual collective consciousness which became the pulse of KB Village, both in urban and rural areas. But unfortunately, until now the institutional process has not been built on the collective consiousness. Even at a certain level, the activities and actions of the government (central / provincial / district) actually reduce the existence of the collective consciousness
\end{abstract}

Keywords: social capital, village KB, participatory, collective awareness

Abstrak

Fakta bahwa Kampung KB mengalami "mati suri" pasca pencanangan menjadi sebuah hal yang tidak terbantahkan. Disisi lain, hasil kajian Meilani dkk (2017) menemukan bahwa sesungguhnya masyarakat sangat menunggu adanya follow up yang lebih nyata dan tentunya periodik dalam rangka pelaksanaan Kampung KB. Penelitian ini bertujuan untuk mengidentifikasi dan menganalisis existing condition modal sosial dalam pelaksanaan Program Kampung KB di Provinsi Riau. Secara konseptual, modal sosial diderivasi ke dalam 4 (emapat) aspek, yaitu nilai dan norma/NN, trust and resiprocity/TRC, informasi/INF, dan networking/NW. Data dikumpulkan melalui observasi dan indepth interview. Informan terdiri dari : (a) Pengurus Kampung KB, (b) Tokoh agama dan tokoh masyarakat di Kampung KB, dan (c) Lurah/Kepala Desa. Analisis data kualitatif dilakukan dengan model interaktif. Hasil penelitian menunjukkan bahwa kehadiran individu yang membawa semangat altruisme dan keikhlasan untuk terus menghidupkan Kampung KB nyatanya sangat menentukan keaktifan dari Kampung KB tersebut. Selain itu, secara kualitatif juga teridentifikasi bahwa bukan tentang hubungan kekeluargaan ataupun ada atau tidak anggaran yang menentukan keaktifan Kampung KB, melainkan kesadaran kolektif (collective consciousness) yang sesungguhnya menjadi denyut nadi Kampung KB, baik di perkotaan maupun pedesaan. Namun sayangnya, sampai dengan sekarang ini belum terbangun proses institusionalisme terhadap collective consiousness tersebut. Bahkan pada level tertentu, kegiatan dan tindakan dari pemerintah (pusat/provinsi/kabupaten) justru bersifat mereduksi keberadaan collective consciousness tersebut.

Kata Kunci : modal sosial, kampung KB, partisipatif, kesadaran kolektif 


\section{PENDAHULUAN}

Program Kampung KB mengalami eskalasi dan cenderung menjadi mainstream dalam program pemerintah kabupaten/kota serta Perwakilan BKKBN Provinsi Riau sejak tahun 2016 hingga kini. Hal ini wajar, mengingat Program Kampung KB itu sendiri merupakan program nasional yang menjadi bentuk pengejawantahan salahsatu "cita-cita" nasional (baca : Nawacita). Dalam perjalanannya, pelaksanaan Kampung KB mengalami berbagai macam diferensiasi baik dari segi proses maupun output sekaligus outcome dan dampaknya di tingkat akar rumput.

Di Provinsi Riau, Kampung KB yang pertama kali dibentuk adalah Kampung KB Ceria di Desa Ransang, Kecamatan Pelalawan, Kabupaten Pelalawan. Kemudian diikuti dengan pencanangan Kampung KB Beringin yang ada di Kelurahan Pesisir, Kecamatan Limapuluh, Kota Pekanbaru. Jumlah Keluarga Pra Sejahtera (KPS) dan Keluarga Sejaktera (KS) I di Desa Ransang memang relatif lebih tinggi jika dibandingkan dengan desa-desa lain di Kecamatan Pelalawan. Sebagian besar masyarakat Desa Ransang bekerja di sebagai nelayan dan perkebunan, akan tetapi taraf kehidupan mereka masih di bawah standar. Selain itu juga tingkat pendidikan terakhir yang ditamatkan masyarakat Desa Ransang adalah Sekolah Dasar (SD). Sedangkan untuk tingkat kesertaan KB di Desa Ransang juga dinilai masih relatif rendah.

Di Kelurahan Pesisir, taraf hidup dan perekonomian masyarakatnya memang masih pada taraf bawah, meskipun di Kelurahan Pesisir dijumpai banyak perusahan dan pabrik. Akan tetapi mata pencaharian penduduk kelurahan Pesisir nyatanya tidak cukup memadai untuk menopang kebutuhan hidup sehari-hari, makanya banyak penduduk yang akhirnya bekerja secara serabutan. Tingkat kesertaan KB di Kelurahan Pesisir sebenarnya relatif lebih tinggi jika dibandingkan dengan keluarahan lain di Kecamatan Lima Puluh. Oleh karena itu, penetapan Desa Ransang dan Kelurahan Pesisir sebagai Kampung KB nyatanya sudah cukup sesuai dengan kriteria penetapan wilayah Kampung KB.

Dari hasil penelitian tahun lalu (Meilani, dkk : 2017) menunjukkan data kuantitatif bahwa dari 79,4\% responden PUS menyatakan bahwa Kampung KB bermanfaat dan 20,6\% menyatakan bahwa Kampung KB tidak bermanfaat. Diantara PUS yang menjawab Kampung KB bermanfaat, manfaat yang terbanyak disebut adalah untuk meningkatkan peserta KB sebanyak 44,4\% responden dan yang paling sedikit dikemukakan adalah adanya perkembangan desa sebanyak 1,2\%. Data ini merepresentasikan bahwa Kampung KB memang masih dipahami sebagai Kampung untuk ber-KB. Filosofi utama Kampung KB yakni mewujudkan kemandirian dan kesejahteraan desa/kelurahan agaknya masih jauh api dari panggang. Oleh karena itu, hasil penelitian tersebut mengidentifikasi berbagai macam isu dan tantangan dalam pelaksanaan Program Kampung KB di Provinsi Riau, antara lain perlunya dekonstruksi konsep dan filosofi Kampung KB, masih kuatnya ego-sektoral yang berakibat pada minimnya koordinasi lintas sektoral, serta tantangan sekaligus ancaman terkait dengan keberlanjutan (sustainability) Program Kampung KB itu sendiri.

Lebih lanjut, Meilani dkk menyebutkan bahwa ada capaian yang berbeda dalam pelaksanaan Kampung KB di Kota Pekanbaru dan Kabupaten Pelalawan. Perbedaan tersebut terletak dari segi keaktifan pengurus dan kader di Kampung KB serta antusiasme masyarakatnya. Temuan di Kampung KB Pelalawan relatif sama dengan fakta dan fenomena di Kampung KB lainnya, yakni Kampung KB masih menjadi sebuah program pemerintah dengan uforia dan formalitas tinggi karena hanya semarak dan proaktif pada saat pencanangan, akan tetapi mengalami "mati suri" pasca kegiatan pencanangan tersebut. Fakta dan fenomena yang berbeda terjadi di Kampung KB Kota Pekanbaru, sebab geliat Kampung KB masih terus dijaga oleh kader dan pengurus Kampung KB. Artinya, Kampung KB Pekanbaru sedikit menepis stereotype bahwa Kampung KB menjadi sebuah program yang tidak memiliki keberlanjutan sekaligus kebermanfaat yang jelas bagi masyarakat. 
Meskipun terdapat kabar baik dari Kampung KB di Pekanbaru, akan tetapi sesungguhnya Kampung KB baik di Kota Pekanbaru dan Kabupaten Pelalawan tetap berhadapan pada persoalan masih rendahnya pemahaman dan partisipasi masyarakat di Kampung KB tersebut. Bahkan muncul skeptisme dari masyarakat setempat terhadap Kampung KB. Hal ini yang kemudian membuat masyarakat enggan untuk melakukan upaya-upaya pengembangan yang sifatnya swadaya dan sukarela, serta cenderung "menunggu" inisiatif dari pemerintah daerah dan/atau Perwakilan BKKBN Riau. Padahal jika dikembalikan pada filosofi Kampung KB, sesungguhnya Program Kampung KB menghendaki terwujudnya kemandirian serta kesejahteraan masyarakat dalam kerangka pemberdayaan masyarakat. Artinya, inisiatif, inovasi, serta keswadayaan masyarakat lokal menjadi faktor kunci apakah desa/kampung tersebut dapat mandiri dan berdaya.

Dalam ranah kajian pengembangan masyarakat (community development), terdapat sebuah aspek yang seringkali dinafikan karena ketersediaan sumberdaya materi dipandang lebih berguna dalam mensukseskan berbagai program pemerintah. Aspek tersebut adalah modal sosial. Sampai disini, dapat ditegaskan bahwa modal sosial berbeda dengan modal materi atau sumberdaya-sumberdaya yang kasat mata dan dapat dihitung nilai materiilnya. Selain itu, modal sosial tentunya memiliki porsi dan peran yang berbeda dengan modal/kapital lainnya terutama dalam mengembangkan sekaligus memberdayakan masyarakat.

Sebagai salahsatu bentuk pemberdayaan ataupun pengembangan masyarakat, Kampung KB memiliki filosofi dan konsep -yang secara normatif — sudah sangat bagus, sehingga tantangannnya adalah bagaimana pelaksanaannya di tingkat akar rumput. Sebagai suatu pemberdayaan masyarakat, eksistensi modal sosial menjadi aspek terpenting yang harus ditemukenali untuk selanjutnya dikembangkan dan/atau diintervensi. Tentunya dalam rangka optimalisasi efektivitas serta efisiensi program Kampung KB, sehingga masyarakat di Kampung KB dapat benar-benar terangkat derajat hidup dan kesejahteraannya serta memiliki kemandirian yang memampukan mereka untuk berperan aktif dalam proses pembangunan baik lokal, maupun nasional (bahkan dimungkinkan dalam konteks internasional).

Kampung KB, sebagai sebuah bentuk program pengembangan masyarakat yang berbasis partisipasi aktif dari masyarakat lokal dan komunitas, secara laten menempatkan modal sosial pada peranan yang penting guna menopang keberhasilan pegembagan masyarakat tersebut. Modal sosial dapat dipergunakan sebagai alat assessment, terutama untuk mengetahui apakah kepercayaan dan partisipasi di dalam masyarakat itu besar atau kecil. Jika tingkat kepercayaan dan partisipasi warga masyarakatnya besar, maka program-program pemerintah (termasuk Kampung KB) dapat dilaksanakan dan dapat diperkirakan akan berhasil. Begitu juga sebaliknya.

Urgensi pentingnya mengelola dan me-manage modal sosial juga ditegaskan oleh Ife \& Tesoriero (2008) yang melemparkan sebuah diskursus "bagaimana mungkin terdapat layanan berbasis-masyarakat jika tidak ada masyarakat yang menjadi basisnya?". Sintesis antara perspektif teoretis dari Ife \& Tesoriero (2008) dengan hasil penelitian terdahulu terkait Program Kampung KB di Provinsi Riau (Meilani, dkk (2017); Rahmeina \& Meilani, 2017) semakin menguatkan akan pentingnya sebuah kajian yang komprehensif dalam rangka menemukenali, mengukur, sekaligus mengintervensi eksistensi modal sosial dalam kerangka Program Kampung KB di Provinsi Riau.

\section{METODE}

Penelitian ini merupakan penelitian kualitatif deskriptif. Setting penelitian ini ditetapkan secara purposive, yaitu di Kabupaten Pelalawan dengan Kampung KB Ceria (Desa Ransang) dan Kota Pekanbaru dengan Kampung KB yang bernama Beringin (Kelurahan Pesisir). 
Data dalam penelitian ini merupakan data primer yang dijaring dengan teknik pengumpulan data berupa observasi, indepth interview, dokumentasi, dan focus group discussion (FGD). Guna menjaring informasi terkait existing condition modal sosial di kedua Kampung KB tersebut (sebagaimana yang menjadi tujuan penelitian yang kedua), akan dilakukan indepth interview dan obersevasi serta studi dokumentasi. Informan dalam indepth interview terdiri dari : (a) Pengurus Kampung KB, (b) Tokoh agama dan tokoh masyarakat di Kampung KB, dan (c) Lurah/Kepala Desa. Analisis data dilakukan dengan menggunalan model analisis kualitatif interaktif (Miles \& Huberman, 1992). Sintesa dari jawaban dari rumusan masalah akan menjadi input bagi tim peneliti untuk merumuskan strategi-strategi dalam rangka penguatan modal sosial Program Kampung KB. Formulasi strategi ini diharapkan mampu menjadi rekomendasi sekaligus intervensi kebijakan yang nantinya akan dilakukan oleh Perwakilan BKKBN Riau dan OPD KB Kabupaten Pelalawan dan Kota Pekanbaru

\section{HASIL DAN PEMBAHASAN}

Modal sosial dapat dipergunakan sebagai alat assessment, terutama untuk mengetahui apakah kepercayaan dan partisipasi di dalam masyarakat itu besar atau kecil. Jika tingkat kepercayaan dan partisipasi warga masyarakatnya besar, maka program-program pemerintah (termasuk Kampung KB) dapat dilaksanakan dan dapat diperkirakan akan berhasil. Begitu juga sebaliknya.

Secara teroretis, banyak tokoh yang kemudian hadir dan mengemukakan perspektif mereka tantang modal sosial. Masing-masing tokoh yang mempopulerkan konsep modal sosial memiliki perbedaan penekanan terhadap unsur yang membentuknya. Perbedaan tersebut juga dalam hal pendekatan analisis. Apapun perbedaan tersebut, intinya konsep modal sosial memberikan penekanan pada kebersamaan masyarakat untuk mencapai tujuan memperbaiki kualitas kehidupan dan senantiasa melakukan perubahan dan penyesuaian secara terus menerus.

Dalam proses perubahan dan upaya untuk mencapai tujuan, masyarakat senantiasa terikat pada nilai dan norma yang dipedomani sebagai acuan bersikap, bertindak dan bertingkah laku serta berhubungan dengan pihak lain. Beberapa acuan nilai dan unsur yang merupakan ruh modal sosial antara lain sikap yang partisipatif, sikap yang saling memperhatikan, saling memberi dan menerima, saling percaya dan mempercayai dan diperkuat oleh nilai dan norma yang mendukungnya. Unsur lain yang memegang peran penting adalah kemauan masyarakat atau kelompok tersebut untuk secara terus menarus proaktif baik dalam mempertahankan nilai, membentuk jaringan kerjasama maupun dengan penciptaan kreasi dan ide baru. Inilah jati diri modal sosial yang sebenarnya (Alfitri, 2011).

\section{A. Nilai dan Norma Sosial}

Nilai merupakan sesuatu ide yang telah turun temurun dianggap benar dan penting oleh anggota kelompok masyarakat. Misalnya nilai harmoni, prestasi kerja, kompetisi dan lainnya. Sedangkan norma merupakan sekumpulan aturan yang diharapkan dipatuhi dan diikuti oleh anggota masyarakat pada suatu entitas sosial tertentu. Norma biasanya terinstitusionalisasi sehingga melahirkan konsekuensi sanksisanksi tertentu.

Dalam kaitannya dengan program Kampung KB, masyarakat di Kelurahan Pesisir dan Desa Ransang merupakan komposisi dan struktur masyarakat yang sebagian besar dari suku Melayu. Nilai sosial yang seringkali diidentikkan dengan masyarakat Melayu adalah nilai kompetisi. Nilai kompetisi dijunjung tinggi tapi dengan tingkatan moralitas yang berbeda-beda. Artinya, masyarakat Melayu relatif terbiasa dengan kompetisi. Hal ini ini pada gilirannya menciptakan tingginya rasa ingin diakui baik dalam bentuk apresiasi maupun legitimasi. Pada gilirannya, membuat sistem kontrol sosial yang bersifat laten menjadi sangat tinggi pada masyarakat Melayu. 
Sedangkan norma yang identik pada masyarakat Melayu adalah norma agama, dimana mayoritas masyarakat Melayu Riau adalah penganut agama Islam, sehingga terbangun image bahwa mayarakat Riau adalah masyarakat yang Islami. Selain itu, beberapa literatur menyebutkan bahwa masyarkat Melayu lekat dengan yang namanya norma formality. Hal ini menciptakan suasana yang khidmat dalam hubungan sosial antar-anggota kelompok atau sesama anggota masyarakat. Tetapi di sisi lain, norma ini cenderung tidak merangsang munculnya ide-ide baru karena semua bentuk hubungan lebih mengutamakan kulit luar yaitu suatu label ketimbang penekanan pada substansi isi.

Maka, sesungguhnya dengan nilai dan norma sosial yang merefleksikan modal sosial, dapat djadikan sebagai enabler dalam rangka pengembangan masyarakat, khususnya melalui Kampung KB ini. Tingginya norma agama dan formality serta nilai kompetisi dalam struktur masyarakat di Kampung KB Beringin dan Ceria, agaknya menjadi entry point untuk penggiatan kegiatan-kegiatan yang sifatnya seremonial dan periodik. Misalnya dalam bentuk lomba, kontes, ataupun bazaar yang di dalamnya memicu para masyarakat dan/atau pengurus Kampung KB untuk mempromosikan Kampung KB-nya. Kegiatan yang sifatnya seremonial dan promotif ini sekaligus dapat menjadi "branding" atas program Kampung KB secara umum. Harapan dari kegiatan semacam ini adalah agar masyarakat di semua lini menjadi tahu, kemudian paham, selanjutnya mereka menjadi tertarik dengan Kampung KB. Dari situ diharapkan juga mulai muncul dampak konkret dari Kampug KB.

Uraian diatas merupakan lesson learned yang dipetik dari pengalaman Kampung KB Beringin. Harus diakui bahwa geliat kegiatan Kampung KB Beringin jauh lebih semarak dibandingkan dengan kampung KB Ceria. Mengapa demikian? Sebab pengurus dan kader Kampung KB Beringin sangat aktif mengikuti kegiatan-kegiatan yang bersifat promotif sekaligus branding untuk Kampung KB Beringin. Misalnya dengan mengikuti lomba-lomba baik di tingkat kota maupun provinsi Riau. Mereka berpartisipasi dalam perlombaan tersebut dengan membawa nama besar "Kampung KB Beringin".

Melalui kegiatan-kegiatan seperti ini, lama kelamaan Kampung KB Beringin memperoleh apresiasi yang positif dari elemen masyarakat sekitar baik individual maupun organisasional. Apresiasi yang pada mulanya hanya berupa pernyataan, lambat laun meningkat menjadi proses pengakuan secara sosial (legitimasi sosial) dalam bentuk berbagai penghargaan yang sudah mereka raih. Pertanyaannya, apakah semua itu mereka peroleh karena adanya dana atau hal-hal yang bersifat materi? Tentu saja tidak. Materi memang penting tapi bukan menjadi suatu prioritas. Kampung KB Beringin bisa maju karena mereka mampu me-manage nilai dan norma sosial yang ada dalam komunitas mereka menjadi suatu hal yang "menggerakkan" mereka untuk mempromosikan hal-hal baik yang selama ini mereka lakukan. Jika demikian, bukankan nilai dan norma sosial itu relatif sama di semua wilayah Provinsi Riau? Oleh karena itu, jika Kampung KB Beringin saja bisa, maka sangat besar peluang untuk melakukan hal yang sama di kampung-kampung KB lainnya, termasuk Kampung KB Ceria.

\section{B. Trust dan Reciprocity}

Trust atau rasa percaya adalah suatu bentuk keinginan untuk mengambil resiko dalam hubungan sosial yang didasari oleh perasaan yakin bahwa yang lain akan melakukan sesuatu seperti yang diharapkan dan akan senantiasa bertindak dalam suatu pola tindakan yang saling mendukung (Putnam, 2002). Trust dapat juga dipahami sebagai sikap saling mempercayai di masyarakat yang memungkinkan masyarakat tersebut saling bersatu dengan yang lain dan memberikan kontribusi pada peningkatan modal sosial (Fukuyama, 1995;2002). Berbagai tindakan kolektif yang didasari atas rasa saling mempercayai yang tinggi akan meningkatkan partisipasi masyarakat dalam berbagai ragam bentuk dan dimensi terutama dalam konteks membangun kemajuan bersama.

Resiprocity menekankan ada pentingnya proses pertukaran antar individu dalam suatu kelompok atau antar-kelompok itu sendiri. Secara teoretis, proses pertukaran sosial (social exchange) yang dimaksudkan disini bukanlah suatu proses yang dilakukan secara resiprokal seketika seperti dalam proses 
jual beli, melainkan suatu kombinasi jangka pendek dan jangka panjang dalam nuansa altruism (semangat untuk membantu dan mementingkan kepentingan orang lain). Seseorang atau banyak orang dari suatu kelompok memiliki semangat membantu yang lain tanpa mengharapkan imbalan seketika. Hal ini seringkali disebut dengan "keikhlasan".

Dalam struktur masyarakat dengan tingkat resiprositas yang kuat akan mampu melahirkan masyarakat suatu masyarakat yang memiliki tingkat modal sosial yang tinggi. Hal ini akan terindikasi pula dari tingginya tingkat kepedulian sosial, saling membantu, dan saling memperhatikan. Terkait dengan resiprositas ini, perlu juga dilihat struktur masyarakatnya apakah terbuka atau tertutup. Kondisi yang sangat konstruktif bagi pengembangan masyarakat adalah jika resiprositas yang kuat dan masyarakatnyna relatif terbuka dengan dunia luar.

Berbicara mengenai trust dan resiprositas di Kampung KB Beringin dan Ceria, kedua aspek ini sudah sangat kuat terasa di kedua kampung KB ini. Rasa saling percaya dan resiprositas yang kuat ditunjukkan dengan semangat untuk mau belajar dan motivasi untuk mengembangkan desanya agar lebih maju lagi melalui kegiatan Kampung KB, meskipun dari segi materi tidak ada gaji atau honor atau insentif yang dijanjikan kepada masyarakat di Kampung KB, khususnya masyarakat dari kelompok kader-kader poktan.

Di Kampung KB Ceria, sambutan hangat dan sangat kekeluargaan begitu terasa selama proses pengumpulan data, padahal tim peneliti adalah individu-individu yang baru pertama kali mereka kenal. Akan tetapi, karena rasa percaya dan dari awalnya sudah memiliki pengharapan serta kepercayaan yang cukup besar terhadap program Kampung KB, maka begitu tim peneliti datang untuk melakukan riset guna perbaikan Kampung KB kedepannya, maka hampir sebagian besar masyarakat (baik kader maupun bukan kader) sangat terbuka dan antusias dalam memberikan data-data yang dibutuhkan dalam penelitian ini. Kondisi ini juga dijumpai peneliti ketika melakukan penelitian di Kampung KB Beringin.

Nuansa altruisme dan/atau keikhlasan sangat terasa ketika didapati informasi dan observasi bahwa terdapat beberapa individu yang dapat dikatakan sebagai "agent of change" dari Kampung KB Beringin dan Ceria. Adalah ibu Nelwati (PLKB Kecamatan Lima Puluh) dan ibu Neni (ketua Kampung KB Beringin), sosok agen pembaharu yang tanpa lelah dan penuh keikhlasan terus menerus menggiatkan Program Kampung KB Beringin.

Kemudian, ibu Yulia, ibu Robiah, dan ibu Ermi, yang kesemuanya merupakan kader poktan di Desa Ransang yang juga sangat proaktif untuk menggerakkan sanak family, tetangga, teman dan seluruh komponen Desa Ransang agar mau ikut berpartisipasi dalam kegiatan Kampung KB. Dari ketiga individu ini, diperoleh pembelajaran berharga bahwa keikhlasan, ketulusan dan kepedulian sosial nyatanya jauh lebih penting daripada hanya sekedar mencari keuntungan materi bagi diri sendiri. Selama proses wawancara dan pengumpulan data di Desa Ransang, sangat terasa betapa mereka ingin membawa desanya agar lebih maju lagi.

Sayangnya, pada konteks Kampung KB Ceria, ketiadaan PLKB yang berstatus ASN pada gilirannya cukup menghambat geliat Kampung KB Ceria. Sebab, meskipun telah hadir individu-individu yang mampu menjadi pembaharu, mereka tetap membutuhkan mentor ataupun fasilitator yang mau dan mampu intens untuk menyambangi Desa Ransang untuk memberikan trigger dalam rangka merangsang inovasi dan kreativitas masyarakat Desa Ransang. Dikatakan demikian sebab, secara sosial budaya, pendidikan masyarakat Desa Ransang masih sangat rendah. Skill yang dimiliki juga terbatas. Oleh karena itu, dalam rangka pengembangan masyarakat, mutlak membutuk pihak luar yang menjadi fasilitator dalam rangka mengintervensi proses pembangunan Desa Ransang. Hal ini bisa jadi dipengaruhi juga oleh kuatnya norma formality yang membuat masyarakat menjadi minim ide dan inovasi. Singkat kata, modal sosial berupa trust dan resiprocity harus dijaga dan dikembangkan secara konstruktif baik di Kampung KB Beringin maupun Ceria, karena jika tidak di-manage dengan baik justru akan menghancurkan segala macam rangkaian proses pembangunan di kedua daerah tersebut. 


\section{Informasi}

Modal sosial dalam bentuk informasi menjadi sebuah aspek yang krusial terlebih di era keterbukaan informasi seperti sekarang ini. Dalam kajian modal sosial ini, analisis kualitatif terkait aspek informasi ini mencoba menggali bentuk-bentuk informasi apa saja yang selama ini dipertukarkan dalam pengembangan Kampung KB serta bagaimana proses pertukaran informasi tersebut, sehingga arahnya adalah mengidentifikasi ada atau tidak potensi (atau bahkan sudah terjadi) assymetric information dalam pelaksanaan Kampung KB di Kabupaten Pelalawan dan Kota Pekanbaru.

Di Kampung KB Beringin, Kota Pekanbaru, informasi yang dipertukarkan baik secara vertikal maupun horizontal dapat dikatakan lebih bervariatif, konkret, dan relatif lengkap jika dibandingkan dengan informasi yang dipertukarkan di Kampung KB Ceria, Kabupaten Pelalawan. Peneliti mencoba menggalinya dari sejak Kampung KB tersebut dicanangkan. Pra-pencanangan Kampung KB, warga masyarakat di Desa Ransang agaknya mengalami "kebingungan" dalam menyerap dan memahami apa itu Program Kampung KB. Masyarakat seolah hanya menjadi obyek yang ketika itu sangat intensif dilatih dan disiapkan untuk acara pencanangan yang memang diselenggarakan secara massive tingkat provinsi. Pemahaman masyarakat Desa Ransang ketika itu bahwa Program Kampung KB adalah program Keluarga Berencana, melulu tentang KB saja. Image inilah yang sampai sekarang terus melekat di masyarakat bahwa desanya adalah desanya KB.

Jika dikaitkan dengan apa yang sesungguhnya pada waktu dilakukan oleh OPD KB Kabupaten Pelalawan dan instansi lainnya, nampaknya ketika itu tidak dilakukan upaya untuk memberikan informasi sekaligus pemahaman yang tepat kepada masyarakat Desa Ransang tentang apa itu Kampung KB. Kondisi ini yang akhirnya sampai sekarang membuat masyarakat Kampung KB Ceria Desa Ransang masih salah dalam memahami Kampung KB. Bahwa memang ada kebanggaan yang besar ketika waktu itu desanya didatangi Gubernur dan pejabat-pejabat tinggi Provinsi Riau, tapi bukan kebanggaan yang berbentuk antusiasme untuk memajukan desanya atas nama Kampung KB.

Lebih lanjut, penyampaian informasi yang parsial dan tidak efektif tidak lantas berhenti ketika pencanangan. Pada waktu pembentukan pokja-pokja Kampung KB pun nyatanya dibentuk dengan dasar "siapa ingat siapa dan siapa tunjuk siapa", bukan berdasarkan kesediaan dari individu yang bersangkutan dan tanpa melihat kemampuan yang bersangkutan. Karena yang menjadi prioritas pada waktu itu adalah yang penting sudah ada nama-nama yang siap untuk dibuatkan SK pokja Kampung KB. Dengan adanya SK tersebut, akan merepresentasikan kesiapan secara teknis sekaligus administratif. Teknik "capcipcup kembang kuncup" ini makin miris ketika nama-nama yang ada tidak diberikan pemahaman sekaligus pelatihan tentang apa-apa saja yang menjadi tugas, hak dan kewajibannya.

Tugas pokok, hak dan kewajiban itu idealnya sudah tertulis dalam SK yang idealnya juga diberikan kepada semua individu yang namanya tertulis di dalam SK tersebut. Sayangnya, SK yang dimaksudkan belum diberikan kepada para kader yang dimaksud, sehingga sampai dengan penelitian ini selesai dilakukan, pengurus Kampung KB Ceria belum semuanya memahami apa tupoksinya termasuk apa sesungguhnya yang menjadi hak mereka. Alih-alih paham tentang apa yang menjadi tugas pokoknya, siapa-siapa saja yang menjadi anggotanya saja masih banyak yang tidak tahu bahkan ketika diminta menyebutkan nama-nama anggota pokja, satu dengan yang lain saling tumpang tindih.

Kondisi yang berbeda dijumpai di Kampung KB Beringin Kota Pekanbaru. Berdasarkan hasil wawancara dan studi dokumentasi, derivasi kebijakan ditemukan lebih runtut dan hirarkhis di Kampung KB Beringin, Kota Pekanbaru. Hal ini nampak dari disahkannya kebijakan di tingkat kecamatan maupun di tingkat kelurahan sebagai derivasi kebijakan yang lebih tinggi yang menjadi dasar pembentukan Kampung KB. Terdapat beberapa derivasi kebijakan yang mendukung dan memayungi Kampung KB Beringin. Seluruh dokumen tersebut di-share secara terbuka oleh PKB maupun Pengurus Kampung KB Beringin. Hal ini mengisyaratkan adanya keterbukaan informasi sekaligus kemudahan untuk mengakses segala bentuk dokumen yang terkait dengan Kampung KB Beringin. 


\section{Jejaring (Networking)}

Aspek jejaring (networking) membicarakan bagaimana individu dalam suatu kelompok atau komunitas memiliki hubungan atau jaringan dengan dunia luar baik secara individual maupun organisasional atau komunitas sehingga dari hubungan tersebut mampu membawa pengaruh dan dampak yang positif baik bagi dirinya sendiri maupun bagi kelompok atau komunitasnya. Jejaring juga dimaknai sebagai sejauh mana komunitas tersebut "bergaul" dengan komunitas lain atau organisasi lain.

Hasil penelitian menunjukkan bahwa aspek jejaring ini masih menuntut intervensi yang lebih intens lagi sebab sampai dengan penelitian ini dilakukan, jejaring baik dari Kampung KB Beringin maupun Ceria masih belum begitu tinggi. Memang dapat dikatakan bahwa pengembangan networking yang selama ini dilakukan di Kampung KB Beringin jauh lebih berdaya guna daripada pengembangan networking di Kampung KB Ceria yang sesungguhnya kurang nampak geliat kegiatannya pasca pencanangan.

Jejaring di Kampung KB Beringin dapat berkembang disebabkan karena sikap terbuka dan tidak menutup diri dari para pengurus Kampung KB dan kader poktan. Wadah dan saluran komunikasi juga sudah terjalin dengan cukup efektif melalui forum Whatsapp Group. Keaktifan pengurus dan kader dalam kegiatan-kegaitan baik di tingkat kota Pekanbaru maupu provinsi juga turut memperluas cakrawala pergaulan dari pengurus Kampung KB Beringin. Terlebih ketika OPD KB Kota Pekanbaru saat ini tengah menjalin kerjasama dengan RRI Pekanbaru. Hal ini tentu saja makin mengoptimalkan peningkatan networking dalam program Kampung KB. Sehingga dapat dikatakan bahwa sejauh mana masyarakat di Kampung KB tersebut bersikap open-minded, hal tersebut akan mempermudah pengembangan jejaring dalam rangka intensifikasi modal sosial yang pada gilirannya akan menjadi enabler yang potensial untuk pengembangan masyarakat secara lebih general.

\section{KESIMPULAN}

Secara kualitatif, kehadiran individu yang membawa semangat altruisme dan keikhlasan untuk terus menghidupkan Kampung KB nyatanya sangat menentukan keaktifan dari Kampung KB tersebut. Selain itu, secara kualitatif juga teridentifikasi bahwa bukan tentang hubungan kekeluargaan ataupun ada atau tidak anggaran yang menentukan keaktifan Kampung $\mathrm{KB}$, melainkan collective effervescent dan kesadaran kolektif (collective consciousness) yang sesungguhnya menjadi denyut nadi Kampung KB, baik di perkotaan maupun pedesaan. Namun sayangnya, sampai dengan sekarang ini belum terbangun proses institusionalisme terhadap collective consiousness tersebut. Bahkan pada level tertentu, kegiatan dan tindakan dari pemerintah (pusat/provinsi/kabupaten) justru bersifat mereduksi keberadaan collective effervescent dan collective consciousness tersebut.

\section{SARAN}

Berangkat dari hasil penelitian diatas, beberapa saran yang dapat diberikan antara lain :

1. BKKBN (pusat dan provinsi) beserta OPD KB Kabupaten/kota perlu merekonstruksi teknis dan operasionalisasi kegiatan yang diselenggarakan di Kampung KB. Berbagai macam kegiatan idealnya memberikan ruang yang lebih luas untuk pelibatan aktif dari warga Kampung KB. Bahkan sampai pada level teknis penyiapan konsumsi kegiatan, idealnya harus mengedepankan partisipasi aktif dari warga Kampung KB, sehingga sekecil apapun kegiatannya membuka peluang bagi warga untuk terlibat karena dari situlah mereka akan dapat belajar mempelajari hal-hal baru yang tentunya akan konstruktif bagi pengembangan Kampung KB. 
2. BKKBN Pusat beserta provinsi perlu untuk duduk bersama dalam rangka menyusun tipologi Kampung KB yang sudah terbentuk sampai dengan 2018. Tujuan dari penyusunan tipologi Kampung KB ini adalah untuk mengidentifikasi positioning dari masing-masing Kampung KB, sehingga tingkat kegagalan atau keberhasilannya dapat terdeteksi di masing-masing Kampung KB.

3. Perlu adanya affirmative action dalam rangka mendekonstruksi pemahaman tentang Kampung KB. Affirmative action tersebut misalnya dapat diberlakukan kepada bapak-bapak, sehingga urusan maju mundurnya Kampung KB tidak boleh dipahami hanya menjadi tanggung jawabnya ibu-ibu (kader perempuan). Affirmative action juga bisa diterapkan kepada kalangan remaja sehingga terbangun kesadaran untuk mengembangkan Kampung KB.

4. Perlu adanya rekontruksi PLKB. Bahwa PLKB bukanlah seorang pendamping desa atau Kampung KB. PLKB dapat menjadi fasilitator yang menjembatani munculnya pendamping organik Kampung KB.

5. Peningkatan kapasitas dan ketrampilan teknis dari para kader Kampung KB oleh BKKBN Provinsi. Perlu dilakuan revitalisasi modal sosial dengan cara melakukan pemetaan sosial di masing-masing Kampung KB.

\section{DAFTAR PUSTAKA}

[1].Akdere, 2005. Social Capital Theory and Implications for Human Resource Development. Singapura Management Review. 27.1.

[2].Alfitri, 2011. Community Development; Teori dan Aplikasi. Yogyakarta : Pustaka Pelajar.

[3].Badaruddin. 2005. Modal Sosial (Social Capital) dan Pemberdayaan Komunitas Nelayan, dalam Isuisu Kelautan dari Kemiskinan hingga Bajak Laut. Yogyakarta: Pustaka Pelajar.

[4].Bourdieu, P. 1986. The Forms of Capital. In J. Richardson (ed). Handbook of Theory and Research for Sociology of Education. New York: Greenwood Press.

[5].Coleman, James S.. 2008. Dasar-Dasar Teori Sosial. Diterjemahkan oleh Imam Muttaqien, Derta Sri Widowati \& Siti Purwandari. Bandung: Nusa Media.

[6].Fukuyama, Francis. 1995. Trust: The Social Virtues and The Creation of Prosperity. New York: Free Press.

[7].Hikmat, Harry. 2004. Strategi Pemberdayaan Masyarakat. Bandung: Humaniora.

[8].Ife, Jim \& Tesoriero, Frank. 2008. Alternatif Pengembangan Masyrakat di Era Globalisasi; Community Development (edisi ke-3). Yogyakarta : Pustaka Pelajar.

[9].Lawang, Robert, M.Z. 2005. Kapital Sosial, Dalam Perspektif Sosiologik. Jakarta: FISIP UI Press. 
[10].Meilani, Nur Laila dkk. 2017. Laporan Akhir Studi Evaluasi Kampung KB di Provinsi Riau. PSKPW Universitas Riau bekerjasama dengan Perwakilan BKKBN Riau dan PUSNA BKKBN Pusat (tidak dipublikasikan).

[11].Nasdian, Fredian Tonny. 2014. Pengembangan Masyarakat. Jakarta : Yayasan Pustaka Obor Indonesia.

[12].Putnam, Robert D. 1993. The Prosperous Community; Social Capital and Public Life. TAp.

[13].Rahmeina, Fauziah Riska \& Meilani, Nur Laila. 2017. Koordinasi dalam Pelaksanaan Program Kampung KB di Kota Pekanbaru. Skripsi pada Prodi Administrasi Publik FISIP Universitas Riau.

[14].Rukminto, Adi Isbandi. 2003. Pemberdayaan, Pengembangan Masyarakat dan Intervensi Komunitas. Jakarta: Lembaga Penerbit Fakultas Ekonomi Universitas Indonesia.

[15]. Rukminto, Adi Isbandi. 2008. Intervensi Komunitas, Pengembangan Masyarakat Sebagai Upaya Pemberdayaan masyarakat. Jakarta: Rajawali Pers.

[16].Soetomo. 2006. Strategi-strategi Pengembangan Masyarakat. Yogyakarta: Pustaka Pelajar.

[17].Suharto, Edi. 2005. Membangun Masyarakat Memberdayakan Masyarakat. Bandung: Refika Aditama 